\title{
On the Role of Red Culture Resources in Ideological and Political Education for College Students
}

\author{
Rui Wang \\ Student Development and Affairs Center of Bohai University, 121000 Jinzhou, Liaoning, China
}

Keywords: red culture resources; ideological and political education for college students; significance; strategy

\begin{abstract}
This paper elaborates the connotation of red culture resources, explores the significance on ideological and political education for college students, further puts forward strategies and methods to promote the role of red culture resources in ideological and political education for college students so as to get red resources penetrated into the life and study of college students and improve the pertinence and effectiveness of ideological and political work for college students.

Red culture resources are rich in content and deep in connotation with far-reaching significance, strong patriotism and educational value, which is highly compatible with ideological and political education for college students. Red culture resources have an important significance on strengthening the ideological and political education, give full play its unique educational function, penetrated into life and study of college students, enrich teaching content, stimulate teaching method and means so as to improve the pertinence and effectiveness of ideological and political education work for college students.
\end{abstract}

\section{The Connotation of Red Culture Resources}

There is not a unified definition of red culture in academic field. Red culture resources refer to historic culture in special period of Chinese revolution, as a kind of cultural heritage, which mainly embody the material and spiritual aspects in the period of social revolution, including a series of revolutionary cultural relics, documentary materials, literary and artistic works, classic revolutionary song and revolutionary war site and relic, monument, revolutionary base area, former residence of revolutionary leaders after the establishment of CPC, revolutionary spirits, revolutionary tradition and cultural heritage and so on.

\section{The Significance of Red Culture Resources on Ideological and Political Education}

The content of red culture resources as ideological and political education for contemporary college students include material and spiritual aspects, which provide rich and vivid resources in educational resources and education of various forms, therefore, the deep exploration on educational value of red culture resources has an important significance on ideological and political education.

\subsection{Innovate carriers of education content}

Red culture resources as an important content in ideological and political education for college students, is the fine tradition formed by the Party in the practice of revolutionary struggle based on socialist civilization and morality, with lofty ideal, belief and moral sentiments. It is not only precious education theoretical resources and material, but also an educational method and means. The value connotation of rich cultural resources in red culture indicates the nature of the CPC, showing fine traditions of self-reliance and arduous struggle, the relation between theory and practice, scientific attitude of seeking truth from facts, work style of relying on the masses, uniting the masses and closely contacting with the masses, innovative spirits of constantly striving to become stronger, and revolutionary courage of keeping pace with the time, exploring and 
innovating, which is beneficial to help college students to foster correct overlooks on the world, life and values. Therefore, red culture and ideological and political education for college students are in a dialectical united relationship, complementing each other.

\subsection{Enrich education method}

At present, teaching methods in higher education activities mainly are teaching material and courseware, supplemented by video and pictures. The simple education form of red culture resources cannot effectively arouse students' interests, and cannot help students deeply understand precious cultural and spiritual connotation in red culture. Red culture resources as the value form of advanced culture in new era provide abundant theoretical materials for ideological and political education for college students. Therefore, it is necessary to pay attention to the theoretical value of red culture resources, enrich classroom knowledge, enhance theoretical attainment, perform corresponding transformation and innovation on education methods with the continuous exploration of knowledge, choose appropriate teaching methods according to specific situations, and change current teaching method based on actual situation of students to enhance the appeal of teaching content; in addition, in teaching practice, it is essential to start from daily life of students, innovate teaching practical activities, and strengthen the attraction and appeal to promote the successful process of activities and the achievement of teaching objectives.

\subsection{Improve the effectiveness of ideological and political education for college students}

College students, as new emerging forces for nation construction, shoulder the historic mission of inheriting red culture and red spirits. Classroom teaching, as the most basic and most important teaching form in colleges and universities, is the main approach to cultivate the outlooks on the world, life and values of college students and foster their spiritual quality, and ideological and political course in higher education is the main approach for college students to obtain red culture education. Therefore, it is necessary to take classroom teaching as main method, conduct the targeted red culture education based on actual situations for college students, and teach content, theoretical basis, historic significance to students more vivid to improve teaching effects and stimulate the initiative of students to learn red culture, promote the effective achievement of teaching objectives and help students realize self-education and self-improvement.

\subsection{Stimulate students' initiative and interests to learn red culture by practical teaching activities}

Classroom teaching is mainly to conduct the teaching of theoretical knowledge to help students have a preliminary and perceptual cognition of red culture resources, whereas, practical teaching activities are the main method of ideological and political education to supplement and perfect theoretical knowledge learning as an important form. Classroom teaching is experiential education of practice with the combination of theory and practice. Practical activities improve the appeal and cohesion of ideological and political education to some extent, increase the interests, effectively strengthen students' understanding of society, cultivate the sense of social responsibility, improve the effectiveness of ideological and political education and give full play to the greatest value of red culture resources. The deep exploration on educational connotation and value of red culture resources has a significant influence on the guiding education of outlooks on values and the world for college students.

\subsection{Foster patriotic enthusiasm of college students}

Patriotism is the fine tradition of the Chinese nation. The promoting of national unity is the cohesion. The current ideological status of college students is closely related to the future prospect and hope of the nation. Ideological and political education is main content and direct approach to patriotism education. Red culture resources enrich scientific value connotation, showing fine traditions of self-reliance and arduous struggle; scientific attitudes of linking theory with practice and seeking truth from facts; work style of relying on the masses, uniting the masses, and closely contacting with the masses; cultural innovative spirits of constantly striving to become stronger, and 
revolutionary courage of keeping pace with the time, exploring and innovating and so on. Valuable red culture is cultural essence accumulated in historic progress of revolution of the CPC with profound historic contents and value connotation. For college students, it is essential to strengthen patriotism education, and improve the awareness of unexpected development to be concerned about the country and people, and be willing to contribute their life wisdom and power to the country, people and socialist construction.

\section{Strategies to Promote the Role of Red Culture Resources in Ideological and Political Education for College Students}

The peculiarity and irreplaceability of red culture is out of the range of red culture in other regions. However, the development of red culture is shown by some simple texts or images in static phase of demonstration. The deep exploration of red culture and effective integration of spiritual connotation and cultural connotation not only can arouse the emphasis on the inheritance and carrying-forward of Chinese traditional culture, but also is beneficial to carry forward educational advantages of red spirits, and enrich the connotation of red culture, and the connotation of ideological and political education in colleges and universities.

\subsection{To enrich ideological and political content of red culture in colleges and universities}

Red culture resources including red culture spirit, the spirit of seeking truth from facts, the spirit of arduous struggle and other Chinese traditional cultural spirits shall be involved in ideological and political course, and practical activities of red culture shall be applied in the daily life of college students, which can subconsciously affect their ideology and behaviors to foster correct ideal and belief. In addition, it is feasible to continuously exert the advantages of red culture resources, strengthen the content of ideological and political education, enrich and innovate work methods and means, and conduct ideological and political education based on the exploration on Yan'an red culture resources, so as to effectively improve the guidance of individual moral quality under the influence of excellent spiritual connotation and promote the comprehensive development of college students.

\subsection{To deep explore the spirit of times and educational value of red culture resources}

Red culture resources contain excellent Chinese historic culture and traditional culture, lofty moral attainment and prominent characteristics of striving to become stronger and overcoming difficulties. The deep exploration on educational connotation and value of red culture resources has an important significance on the positive guidance of students' outlooks on values, the world and life. Based on the deep exploration on the background, connotation and important significance of red culture resources, it is necessary to conduct ideological and political education for college students to encourage them to consciously enhance their moral quality under the excellent spirit connotation, and guide their behaviors to promote their comprehensive quality.

\subsection{To strengthen the promotion of contemporary value of red culture resources}

Red culture resources not only inherit Chinese excellent historic culture and traditional culture, and the spirit of times and educational value is self-evident. Therefore, the deep discussion on the educational connotation and value of Yan'an red culture resources and promotion of contemporary value of red spirits are beneficial to strengthen the sense of social responsibility and sense of belonging of the public, especially college students. The current ideological and political courses in colleges and universities shall perform the education from the perspectives of study objectives, thinking concept, ideal and belief, and focus on the function of moral education of red culture resources, which has an important significance on the positive guidance of college students' outlooks on values, the world and life. 


\section{Conclusion}

Red culture resources is high-quality and irreplaceable educational resources with scientific connotation and spiritual value, and precious material for ideological and political education in new era. It not only carry excellent Chinese historic culture and traditional culture, also contain noble moral quality. High-quality ideological and political educational resources include spirit of arduous struggle, striving to become stronger, and actively forging ahead, excellent quality, patriotism education, education of nation spirits, education of ideal and belief, education of will and character and so on, which has an important and far-reaching significance. Therefore, in recent years, many colleges and universities have realized the importance and necessity of red culture resources in ideological and political education, based on the effective integration of red culture educational resources, deeply discussed application methods and means of ideological and political education, with red culture resources as carrier, and strengthen the ideological and political education for college students in new era.

\section{References}

[1] Zhong Limin. On Economic Value and the Realization of Red Culture [J]. Truth Seeking, 2010(03):84.

[2] Wang Yidi. The Value Connotation of "Red Culture” [J]. Theory Horizon, 2007(08):149-150.

[3] Liu Yuexi. On the Important Influence of Red Culture on Contemporary College Students [J]. Forum on Contemporary Education, 2006(10):23.

[4] Cai Hongli. Red Culture and the Construction of Socialist Core Value for College Students [J]. Forum on Contemporary Education, 2012(6):28. 